\title{
Entrepreneurial narrative identity and gender: a double epistemological shift
}

\begin{abstract}
A double epistemological shift is proposed to challenge the enduring dominance of the discourse of entrepreneurial masculinity which impedes our understanding of entrepreneurship. First, a re-framing of the epistemological status of narrative supports philosophical and theoretical approaches to the constitution of narrative identity. Second, an epistemological shift to understand gender in entrepreneurship through the constitution of gendered identities in discourse is proposed. These shifts invoke the ontological dimension of narrative and contemporary theories of gender to understand entrepreneurial identity as coconstituted and located in repertoires of historically- and culturally-situated narrative. This offers new theoretical and methodological possibilities in entrepreneurship.
\end{abstract}

\section{Introduction}

In this paper post-structuralist feminist theorising of gender and discourses (Sunderland 2004) contributes an understanding of gender identities constituted and positioned in entrepreneurial narratives. A post-structuralist perspective draws attention to how particular knowledge is produced and also to 'what has been obscured or made invisible' (Fletcher 2001: 23). Historically, women's entrepreneurship has been neglected by researchers and it is, in this sense, rendered invisible (Ogbor 2000; Hamilton 2013a). Ahl's (2006) critique of women's entrepreneurship research triggered 'an outpouring of scholarly interest' (Hughes, et al. 2012: 430) but there is much to be done in terms of developing a more refined understanding of entrepreneurship and gender. It remains the case that entrepreneurship research pays scant attention to gender dynamics, and that explicit feminist analysis is rare 
(Reed 1996; Mulholland 1996; Mirchandani 1999; Bruni, et al. 2004; Hamilton 2013a; 2013b).

To develop fresh understandings of gender in entrepreneurship this paper proposes a double epistemological shift. The first epistemological shift invokes the ontological dimension of narrative, moving beyond an understanding of narrative as mere method. The second shift proposed develops contemporary theories to understand gender in entrepreneurship through the constitution of gendered identities in discourse, gender as coconstituted and located in repertoires of historically and culturally situated narrative. This supports a way to challenge the enduring dominant discourse of entrepreneurship as embodying particular forms of masculinity.

This paper responds to the call for this Special Issue to engage with post-positivistic epistemologies in order to challenge dominant perspectives and offer new ways to theorise the field of entrepreneurship. A post-positivistic research approach assumes that research methods applied in any study should be determined by the nature of the research question. Whilst a positivist paradigm relies on quantitative studies, a post-positivistic approach would include a range of qualitative, interpretive methods. Entrepreneurship research has been identified as dominated by positivist studies and a number of leading scholars in the field have advocated more methodological pluralism (Gartner, and Birley 2002; Neergard, and Ulhoi 2007; Anderson, and Starnawska 2008). The double epistemological shift proposed here can support the development of fresh methodological approaches to theorise entrepreneurship.

Narrative research approaches have shown much promise in enhancing our grasp on some of the subtleties and complexities of entrepreneurship (Larty, and Hamilton 2011). Narrative in management studies was established by scholars such as Boje $(1995 ; 2001)$ 
Czarniawska (1998; 1999; 2004) and Gabriel (2000). They argued that narrative research approaches were particularly useful in the study of complex organisations. Some of the key debates around narrative in management studies centred, first, on the relationship between narrative and storytelling; second, on the definition and role of plot; and, finally, on the epistemological status of narrative. This paper joins those debates in arguing for a reexamination and extension of the status of narrative, drawing on wider theoretical and philosophical debates. This entails an epistemological re-framing narrative as an ontological condition of the social world rather than simply a representational form, or a methodological approach. It relies on an understanding that 'social life is itself storied and that narrative is an ontological condition of social life' (Somers, and Gibson 1993: 2; italics in original; Somers 1994: 614). Narrative re-framed moves from being a methodological device to an ontological condition of social life and social structures.

Prior to 2002 narrative studies in entrepreneurship represented a relatively small field of work (Smith, and Anderson 2004) but there were some influential early pioneers (Steyaert 1997; Pitt 1998). Johansson (2004) highlighted the emergence of interest in the use of a narrative approach in entrepreneurship studies, particularly in the construction of entrepreneurial identity, in understanding entrepreneurial learning and in efforts to reconceptualise entrepreneurship. Advocates of the approach continued to emerge (for example, Smith 2005; Hamilton 2006a; 2006b; Gartner 2007; Larty, and Hamilton 2011). The special editions edited by Hjorth and Steyaert $(2003 ; 2004 ; 2009)$ provided an important outlet for scholars engaging with narrative approaches in entrepreneurship.

Narrative mediates and constitutes experience: identities (multiple and complex) draw upon, and are located within, a repertoire of narratives (Ricoeur 1991b). The notion of selfidentity (an entrepreneur) interacts with broader social structures (gender). In forging their 
self-identity individuals contribute to and promote 'social influences that are global in their consequences and implications' (Giddens 1991: 2). There has been a growing body of interest in notions of entrepreneurial identity (see for example Cohen, and Musson 2000; Down, 2006; Warren 2004; Down, and Reveley 2004; Down, and Warren 2008; Downing 2005; Essers, and Benschop 2007; Watson 2009; Anderson, and Warren 2011). Identity and processes of identification matter because 'it is how we know who's who and what's what' (Jenkins, 2008: 13). Goffman (1959) introduced the idea of identity as performance and the communication of gender stereotypes through advertising, which bridges to the theorising of gender as performance (Butler 2010). In entrepreneurship research Ahl (2006) called for an epistemological shift to examine 'how gender is accomplished' (p.612; italics in original), as opposed to relying on objectivist assumptions regarding gender. The objectivist stance focusing on gender as an individual characteristic, something essentially male or female that can be measured and used as an explanatory variable ignores the role of the social and cultural in constructions of gender (Ahl 2006; Gatrell, and Swan 2008). The theoretical connections between identification processes, gender and language offer new opportunities in entrepreneurship research.

Down (2006) was amongst the first to focus on an entrepreneurial self identity, an identity that is not a 'categorical essence' but something fluid in space and time and constructed in relation to others (p.6). Watson (2009) provides an erudite account of work to date in this area. He concurs with Down (2006) that entrepreneurial identities are not something that "individuals "have" (p.255) but are more helpfully considered as related to cultural and discursive repertoires. He distinguishes between self identity and social identities connected to wider discourse, as interconnected aspects of identity work (p.251). Down (2006), on the other hand, influenced by Somers (1994), views self and society not as separate entities but different aspects of a 'social whole'. These studies of entrepreneurial 
identity have included both men and women in the gathering of empirical materials. Even in these studies, however, we can find the resilience of a male norm in entrepreneurship. Down (2006) for example relies on male participants to provide empirical materials to examine entrepreneurial identity. Warren (2004) acknowledges a mainstream entrepreneurial discourse (masculine) that women entrepreneurs identified themselves as partially resisting in constructing alternative identities. Watson (2009) provides a rich account of the dialogue between two cousins in a family business, emphasising the relational and dialogic nature of identity work (p.266). Of the cousins, one female one male, it is the male that is cast as the more entrepreneurial: 'doing deals'; 'a bit of an outsider at school'; 'passionate' (p.266). This growing body of valuable work provides a strong platform for theorising entrepreneurial identity, and an opportunity to build on our understanding of gender and entrepreneurial identity.

In seeking to extend our understanding of entrepreneurial identity production and knowledge Anderson and Warren (2011) argue that 'the label, an entrepreneurial identity is sufficiently malleable to allow practising entrepreneurs to employ it to build their own individualized identity' (p.605). However, the subject of their study is Michael O'Leary a well-known 'flamboyant entrepreneur' (p.589). The gendered nature of his identity construction and use as a 'rough tongued entrepreneurial jester' (p.603) is reinforced and reproduced by the media in a way that perpetuates the exclusionary nature of that identity. Anderson and Warren (2011) note that 'the entrepreneurial discourse has become a legitimizing frame of entrepreneurial meaning' (p.592) but the question remains about the framework being provided by an identity construction where 'his ostentatious displays are brash, uncouth invectives; his tirades employ obscenity tempered with saucy humour' (p.603). The enduring individualistic, masculine, ethnocentric discourse has been identified by a number of researchers (Achtenhagen, and Welter 2003; Baker, et al. 1997; Hamilton 
2006 b; Ljunggren, and Alsos 2007; Ogbor 2000; Radu, and Redien-Collot 2008). Nicholson and Anderson (2005) in a study of the metaphoric portrayal of entrepreneurship in the UK media 1989-2000 concluded 'the entrepreneurial myth remains resolutely male' and articulated 'the maleness of enterprise' (p.162).This dominant discourse is serving to inhibit insight into the diversity and complexity of the phenomenon of entrepreneurship (Hamilton 2013a; 2013b). The entrepreneurial myth 'is ideological rather than representational' and 'offers a sense making framework' (Anderson, and Warren 2011:164) but it is exclusionary and selective in whom it offers a frame with which to identify.

This paper proposes a double epistemological shift in narrative and gender to offer new understandings of entrepreneurial identity constructed socially in relation to others, shaped by multiple discourses. The first shift proposed acknowledges the ontological dimension of narrative, moving beyond an understanding of narrative as mere method. The second shift proposed develops an understanding of gender as co-constituted and located in repertoires of historically and culturally situated narrative. This could provide a platform for new method and theory in entrepreneurship. It explores the co-constitution of negotiated, complex gender identities and the practices associated with those identities over time. These relationally defined selves are set within cultural and social boundaries including existing dominant discourses, such as the dominant discourse of entrepreneurship as individualised and masculine. An assumption that entrepreneurship is a masculine endeavour, and that entrepreneurial identity is most naturally male, stubbornly endures in entrepreneurship research (Hamilton 2013a; 2013b). It replicates and reinforces what seems at times surprising gender blindness in the field. At the same time there have been calls to define gender as ways of being, made available through discourses (Swan 2006; Wagner, and Wodak 2006; Ahl 2006). The concept of narrative identity with its historical, spatial and relational implications 
(Somers 1994) offers an opportunity to generate new insights and new ways of theorising the field of entrepreneurship.

\section{Extending the epistemological status of narrative}

A re-framing of the epistemological status of narrative, already adopted in other disciplines, supports a philosophical and theoretical understanding of narrative identity and its central role in how we configure and reconfigure our experience. Our narrative capacity is fundamentally part of the human condition and our social world (Barthes 1977). The concept of narrative lies at the heart of academic study of the humanities (Reissman 2008). Given this, can narrative be termed a post-positivistic epistemology? The justification for so doing is that in the domain of the social sciences the concept of narrative has been denied legitimacy in epistemological terms (Czarniawska 2004, p.7). "Every knowledge discipline needs an 'epistemological other' to consolidate a cohesive self-identity and collective project"(Somers, and Gibson 1993: 1; Somers 1994: 613). This otherness is upheld by defining narrative as a representation of social knowledge and positioning it in contrast with causal explanation. Dichotomies become perpetuated in positioning our research such as particular versus generalisable, discursive versus quantitative, descriptive versus theoretical, exploratory versus explanatory and a value is placed on the research in terms of the labels. Defining narrative as representational casts it in opposition to, and requiring distance from, the explanatory.

A re-framing of narrative emerged in the early 1990s in the social sciences based on philosophical understandings of narrative beyond representation, something more substantive. Czarniawska (1999) points to a 'literary turn' in the social sciences in the 1990s which led to a fresh consideration of the type of knowledge produced by social scientists and 'opening the door to narrative knowledge' (italics in original, p.14). What she termed the 
narrative mode of knowing, she argues, 'changes the task of the researcher' (p.15). Paul Ricoeur (1991a; 1991b) was at the forefront in this ontological re-framing of narrative, arguing that the concept of emplotment (muthos) mediates the human experience of time. In developing a view of narrative as dynamic over time, Ricoeur draws on the notion of emplotment signifying both imaginary story (fable) and well-constructed story (plot). Elements of plot take their place in a unified story, but emplotment is an integrating, dynamic process not a static structure. Configuring and re-configuring narrative makes sense of experience, provides alternative courses of possible action, or is used as a form of communication. Narrative's 'temporal dialectic' combining two dimensions, one episodic and the other configurative (Ricoeur 1991b: 78) On the one hand narrative helps us to parcel up meaningful experiences into a connected, coherent episodic bundle. On the other hand we can, drawing on narratives available to us and our capacity to configure and re-configure, shape interconnected narratives that construct our identities. The ontological dimension of narrative thus encompasses both identity and social action.

We are always reinterpreting our identity drawing on narratives available to us via our culture embedded in our social and historical context (White 1991; Wood 1991). Existing ideologies constrain what may be possible in terms of that identity in any given cultural context. This is the great difference between life and fiction, that we can become our own narrator, but only in imitation of narrative voices available to us. Ricoeur believes that 'unbridgeable gap' is only partially abolished by our ability to emplot (p.32). However the 'pre-interpreted' nature of our experience does allow for emancipatory possibilities from the constraints of social and cultural norms, 'symbolic codes are not transmitted in any straightforward way into individual practice' (McNay 2000: 77). Boje (2001) built upon Ricoeur's work to consider 'who gets to author the plot' (p.108), and emphasised the interplay between our pre-understandings, the plot and our 'embedded contextuality' (p.121). 
The active dynamic suggested by emplotment denotes the idea that individuals do not passively absorb external determinations but are actively involved in interpreting experience and, related to those interpretations, forming their identity over time. The temporal dimension of identity formation offers a way to move beyond the notion of subjectivity as either fragmented and in permanent flux or inevitably shaped by normalising social forces. This idea of narrative identity shares a post structural emphasis on the constructed self but the narrated identity also suggests constraints and limits to the ways in which identity might be changed. These constraints are not only imposed by social and historical possibilities but also imposed in the process of emplotment, in our moving back and forth, fitting together events and existing plots. Experience is constituted through, and mediated by, narrative. Identities (multiple, fluid and complex) draw upon and are located within a repertoire of narratives.

This new ontological dimension of narrative was gradually appropriated into the epistemological frameworks of a spectrum of disciplines in the 1990s including medicine, social psychology, anthropology, gender studies, law, biology, and physics (Somers, and Gibson 1993:1; Somers, 1994: 613; Czarniawska, 1999). In entrepreneurship research such an appropriation, extending the status of narrative in entrepreneurship research beyond a form of representation or mere method, way beyond the anecdotal, is perhaps long overdue.

\section{Narrative identity: gender constructed in discourse}

Narrative provides coherence and meaning to the flux of events but is never fixed, it is always open to interpretation or re-configuring. Narrative is the medium through which the 'inherent temporality of being is expressed' (McNay 2000: 85). It shapes identity and is the way in which selfhood is expressed. Ricoeur (1991b) and McNay (2000) are clear, however, that narrative does not determine identity. Narrative mediates the generative configuration, and reconfiguration, of identity. This can support a view of identities as multiple, ambiguous 
and sometimes contradictory. Kondo (1990) contrasts this with what she sees as a Western view of identity as a whole subject, the master subject, fixed, coherent, bounded, containing some essence that is expressed in certain distinctive attributes. She challenges our assumptions about individual identities and thus provides the basis for 'a radical critique of “'the whole subject', in contemporary Western culture.' (p.33). McAdams (1997), in taking a view of self and identity which he labels postmodern, stresses the multiple selves which we seek to unify, in his view through narrative and life story-telling: 'While the multiplicity of (post)modern life renders it unlikely that a person's me can be packaged neatly into a narrative form, adults still seek to bestow upon the me a modicum of unity and purpose (i.e. identity) by constructing more or less coherent, followable and vivifying stories' (p.63).

In any examination of identity and gender there is a danger of falling into the trap of essentialism, in terms of what is defined as masculine and what is defined feminine. It has been argued that in order to avoid essentialism we need to incorporate into the core conception of identity the dimensions of time, space, and relationality' (Somers, and Gibson 1993). Post-structuralist feminist theorising of gendered discourses (Baxter 2002; Bruni, et al. 2005; Sunderland 2004) provides opportunities to examine in more intricate ways the dominant masculine discourse of entrepreneurship. An entrepreneurial narrative is crafted within complex, delicate, constantly changing relationships. Identities and notions of self are revealed as more intricate and difficult to define than suggested by the dominance of patriarchal power.

Narrative interpretation entails understanding the construction of gendered identities in discourse (Cameron 1998; Talbot 1998; Sunderland 2004). Sunderland (2004) suggests we can understand gender in discourse as operationalising gender, not defining it. This is to enable the claim that 'something to do with gender is going on' (Sunderland 2004: 172). The 
next section draws on Sunderland's (2004) discussions to help frame an exploratory empirical and theoretical examination of gender construction drawing on the empirical material.

\section{Co-constitution of gender identity}

The intricate complexity of gender identity is negotiated, disrupted and repaired in the course of everyday conversations, undertaking what Sunderland (2004) calls negotiated interaction in the construction of gender. Subtle relationships of duty, love, power and conflict are implicated in the constitution of our multiple, complex and shifting identities (Kondo 1990). Universal explanations of gender categories are problematic. Discourse constructs gender, but discourse can be actively used, produced to perform gender (Sunderland 2004). Individuals define themselves in relation to each other and to wider discourses available to them. Entrepreneurial identities are contested and legitimised at the same time. Our identities are more fractured, open and contested than a categorisation into masculine or feminine allows. We are, however, being located or locating ourselves in wider discourses, 'in social narratives rarely of our own making' (Somers 1994: 606). These narratives can legitimate and constrain what is possible in identity construction. As Jenkins (2008) points out in terms of identity 'classification is rarely neutral' (p.6). So the dominant discourse of entrepreneurship as a particular form of masculinity requires challenge, in order to open up new possibilities.

\section{Discussion}

A view of gender as fluid, constructed and negotiated in terms of everyday lives in the context of the multiple but socially and culturally bounded discourses available to us emphasises that it is important to examine the available discourses in entrepreneurship.

Ricoeur's philosophical understanding of the relationship between narrative and identity suggests whilst we are always reinterpreting our identity drawing on narratives available to us 
via our culture we are embedded in our social, cultural and historical context (Wood 1991). Clearly discourses are diverse and multiple, they are 'operating alongside, converging with, jostling and temporarily mingling with other discourses' (Sunderland 2004: 193). Some discourses endure for centuries; some are fleeting or newly emerging.

The importance of the constraints imposed by existing ideologies and their coercive nature should not be underestimated. These constructions of gender identity should be understood within wider sets of gender relations and prevailing discourses. We must be reminded that, 'selves were never separable from context: that is, from the situations in which they were performed, the audience to whom the narrative production of self was addressed, the exclusions implicit in any construction of "self", the historical and political/economic discourses and the culturally shaped narrative conventions that constructed the "self", (Kondo 1990: 247). The re-framing of narrative, the epistemological and ontological shift, means that 'it is through narrativity that we come to know, understand, and make sense of the social world, and it is through narrativity that we constitute our social identities' (Somers, and Gibson 1993: 27).

Entrepreneurship studies identify an entrepreneurial myth 'more vivid and persistent than expected' and one that 'remains resolutely male' Nicholson and Anderson (2005: 162). The stubborn endurance of a dominant discourse of entrepreneurship as a particular form of masculinity has been challenged (Ahl 2006; Ahl, and Marlow 2011; Hamilton, 2013a). But there remains work to be done in achieving an epistemological shift which has been called for in the study of gender and entrepreneurship. The archetype of the entrepreneur as male is symbolically and materially represented in the media and reproduced and reinforced in entrepreneurship research, this impacts on both male and female subjectivities. This 'representational silence' of women in the entrepreneurial narrative presents a barrier for 
women constructing a social identity aligned to the normative forms of the representations of entrepreneurship, symbolic and otherwise (Somers 1994: 630).

This paper suggests ways in which methodologically and empirically we can begin to move forward in conceptualising entrepreneurial identities and practice. There are ways of knowing and understanding experience that are different from the current dominant theoretical discourses, but equally valuable. Post- positivist approaches are underrepresented in entrepreneurship research (Hindle 2004) and have the potential to address fundamental questions (Anderson, and Starnawska 2008). This Special Issue encourages entrepreneurship researchers to consider the theoretical challenges and epistemological shifts required to establish legitimacy for approaches that have been cast as 'the other', the epistemological other in contrast to causal explanation (Somers 1994: 614). It recognises that in challenging dominant theoretical discourses 'getting heard requires new theories' (Somers 1994: 610).

In moving forward empirically, first we can build on the existing foundations in the use of narrative analysis in entrepreneurship, extending the range and depth of literary frameworks employed (Larty, and Hamilton 2011). This is challenging because as entrepreneurship researchers we have to move beyond narrative cast as a method of analysis to an ontological approach that can unlock new understanding of subtle and diverse forms of entrepreneurial identity construction. Second, we can begin to employ explicitly feminist analysis in order to understand the dynamics of gender and identity construction (and use) in the context of entrepreneurship. This will counteract the current exclusionary entrepreneurial myth that is so resolutely framed ideologically as masculine. Here we can learn from the lessons of the over-arching field of management where Broadbridge and Simpson (2011) conducted a review of twenty-five years of gender and management research. They point to the challenge of gender denial, where current conceptualisations assume that gender issues 
have been, in some sense, 'solved'. They suggest future directions of research in revealing gendered practices and processes concealed in norms, customs and values. Whilst the field offers a growing number of approaches both theoretically and methodologically there remain 'increasingly strong calls for scholars to take their research in new directions' (Hughes, et al. 2012: 429).

This paper, in proposing a double epistemological shift in narrative and gender, offers new understandings of entrepreneurial identity constructed socially in relation to others, and shaped by multiple discourses. It moves narrative from being cast as merely a method of research to acknowledging the ontological dimensions of narrative. It relies on understanding the role of language 'in how we think and learn about phenomena' (Nicholson, and Anderson 2005). It develops an understanding of gender as co-constituted and located in repertoires of historically and culturally situated narrative. This provides a platform for new method and theory in entrepreneurship. It calls for the examination of the co-constitution of negotiated, complex gender identities and the practices associated with those identities over time. These relationally defined selves are set within cultural and social boundaries including existing dominant discourses, such as the dominant discourse of entrepreneurship as individualised and masculine. The concept of narrative identity with its historical, spatial and relational implications (Somers 1994) offers an opportunity to generate new insights and new ways of theorising the field of entrepreneurship. It provides a challenge to the dominant theoretical perspectives in terms of what might be legitimate research. It also encourages an explicit engagement with contemporary gender studies to provide a conceptual vocabulary to enhance our research and enrich our understanding of entrepreneurship.

\section{References}


Achtenhagen, L. and Welter, F. (2003). 'Female Entrepreneurship in Germany: Context, Development and its reflection in German Media', in New Perspectives on Women Entrepreneurs. Ed. J.E. Butler. Greenwich, Connecticut: Information Age Publishing, $71-100$.

Ahl, H. (2004). The Scientific Reproduction of Gender Inequality: A discourse analysis of research texts on women's entrepreneurship. Libor: Copenhagen Business School Press.

Ahl, H. (2006). 'Why research on women entrepreneurs needs new directions', Entrepreneurship Theory and Practice, 30 (5), 595-621.

Ahl, H. and S. Marlow (2011). 'Exploring the intersectionality of feminism, gender and entrepreneurship to escape the dead end', paper presented at the EGOS Symposium, Gothenburg, Sweden.

Anderson, A.R., and M. Starnawska (2008). 'Research practices in entrepreneurship: Problems of definition, description and meaning,' The International Journal of Entrepreneurship and Innovation, 9 (4), 221-230.

Anderson, A.R., and L. Warren (2011). 'The entrepreneur as hero and jester: enacting the entrepreneurial discourse,' International Small Business Journal, 29 (6) 589-609.

Baker, T., H.E. Aldrich, and N. Liou (1997). 'Invisible entrepreneurs: the neglect of women business owners by mass media and scholarly journals in the USA', Entrepreneurship and Regional Development, 9 (3), 221-238.

Barthes, R. (1977). 'Introduction to the structural analysis of narratives', in Roland Barthes, Image-Music-Text (translated by S. Heath), Glasgow: Collins, 79-124. 
Baxter, J. (2002). 'A Juggling Act: A feminist post-structuralist analysis of girls' and boys' talk in the secondary classroom' Gender and Education, 14 (1), 5-19.

Boje, D.M. (1995). 'Stories of the Storytelling Organization: A postmodern analysis of Disney as “Tamara-Land”, Academy of Management Journal, 38 (4), 997-1035.

Boje, D.M. (2001). Narrative Methods for Organizational and Communication Research, London: Sage Publications Ltd.

Broadbridge, A., and R. Simpson (2011). '25 Years On: Reflecting on the Past and Looking to the Future in Gender and Management Research' British Journal of Management, Vol. 22, $470-483$.

Bruni, A., S. Gheradi, and B. Poggio (2004). 'Entrepreneur-mentality, Gender and the Study of Women Entrepreneurs', Journal of Organisational Change Management, 17 (3), 256-268.

Butler, J. (2010). 'Performative agency,' Journal of Cultural Economy, 3 (2), 147-161.

Cameron, D. (1998). 'Performing gender identity: Young men's talk and the construction of heterosexual masculinity,' in Language and Gender: A Reader. Ed. J. Coates. Oxford: Blackwell Publishers Ltd., 270-285.

Cohen, L., and G. Musson (2000). 'Entrepreneurial identities: reflections from two case studies,' Organisation, 7 (1), 31-48.

Czarniawska, B. (1998). A Narrative Approach to Organization Studies. Thousand Oaks CA: Sage Publications Inc.

Czarniawska, B. (1999). Writing Management: Organization theory as a literary genre. New York: Oxford University Press Inc. 
Czarniawska, B. (2004). Narratives in Social Science Research. London: Sage Publications Limited.

Down, S. (2006). Narratives of Enterprise: Crafting Entrepreneurial Self-identity in a Small Firm. Cheltenham: Edward Elgar Publishing Limited.

Down, S., and J. Reveley (2004). 'Generational encounters and the social foundation of entrepreneurial identity: "Young Guns" and "old farts", Organisation, 11 (2), 233-250.

Down, S., and L. Warren (2008). 'Constructing narratives of enterprise: clichés and entrepreneurial self-identity,' International Journal of Entrepreneurial Behaviour and Research, 14 (1), 4-23.

Downing, S. (2005). 'The social construction of entrepreneurship: narrative and dramatic processes in the co-production of organisations and identities,' Entrepreneurship Theory and Practice, 29 (2), 185-204.

Essers, C., and Y. Benschop. (2007). 'Enterprising Identities: female entrepreneurs of Moroccan or Turkish origin in the Netherlands,' Organisation Studies, 28 (1), 49-61.

Fletcher, J.K. (2001). Disappearing Acts: Gender, power and relational practice at work. Cambridge MA: The MIT Press.

Gabriel, Y. (2000). Storytelling in organizations: Facts, fictions, and fantasies. New York: Oxford University Press.

Gartner, W.B. (2007). 'Entrepreneurial narrative and a science of the imagination', Journal of Business Venturing, 22, 613-627. 
Gartner, W.B., and S. Birley (2002). 'Introduction to the special issue on qualitative methods in entrepreneurship research,' Journal of Business Venturing, 17(5), 387-395.

Gatrell, C., and E. Swan (2008). Gender and Diversity Management: A concise introduction. London: Sage

Giddens, A. (1991). Modernity and self-identity: Self and society in the late modern age. Stanford: Stanford University Press.

Goffman, E. (1959). The Presentation of Self In Everyday Life. New York: Anchor Press, Doubleday.

Hamilton, E. (2006a). 'Narratives of enterprise as epic tragedy,' Management Decision, 44 (4): 536-550.

Hamilton, E. (2006b). 'Whose story is it anyway? Narrative accounts of the role of women in founding and establishing family businesses,' International Small Business Journal, 24(3), $253-271$.

Hamilton, E. (2013a). 'The discourse of entrepreneurial masculinities (and femininities),' Entrepreneurship and Regional Development, 25 (1-2), 90-99.

Hamilton, E. (2013b). Entrepreneurship across Generations: Narrative, gender and learning in family business. Cheltenham: Edward Elgar Publishing Limited.

Hindle, K. (2004). 'Choosing qualitative methods for entrepreneurship cognition research: a canonical development approach,' Entrepreneurship Theory and Practice, 28 (6), 575-607.

Hjorth, D., and C. Steyaert (2003). New Movements in Entrepreneurship. Cheltenham: Edward Elgar. 
Hjorth, D., and C. Steyaert (2004). Narrative and Discursive Approaches in Entrepreneurship. Cheltenham: Edward Elgar.

Hjorth, D., and C. Steyaert, (2009). (Eds.) The Politics and Aesthetics of Entrepreneurship. Cheltenham: Edward Elgar.

Hughes, K.D., J.E., Jennings, C., Brush, S. Carter, and F. Welter (2012). ‘Extending women’s entrepreneurship in new directions,' Entrepreneurship, Theory and Practice, 36 (3), 429442.

Jenkins, R. (2008). Social Identity, $3^{\text {rd }}$ Edition. Abingdon: Routledge.

Johansson, A.W. (2004). 'Narrating the Entrepreneur,' International Small Business Journal, $22(3), 273-293$.

Kondo, D.K. (1990). Crafting Selves: Power, gender and discourses of identity in a Japanese workplace. Chicago and London: The University of Chicago Press.

Larty, J., and E. Hamilton (2011). 'Literary frameworks for narrative analysis in entrepreneurship research,' International Small Business Journal, 29 (3), 220-237.

Ljunggren, E., and G.A. Alsos (2007). 'Media Expressions of Entrepreneurs: Presentations and Discourses of Male and Female Entrepreneurs in Norway,' in Female Entrepreneurship: Implications for Education, Training and Policy. Ed. N.M. Carter, C.O. Henry, B. Cinneide, and K. Johnston. London: Routledge, 88-109.

McAdams, D.P. (1997). 'The case for unity in the (post)modern self: A modest proposal,' in Self and Identity: Fundamental issues. Ed. R.D. Ashmore, and L. Jussim. Oxford and New York :Oxford University Press. 
McNay, L. (2000). Gender and Agency: Reconfiguring the subject in feminist and social theory. Maiden, Mass: Polity Press.

Mirchandani, K. (1999). 'Feminist Insight on Gendered Work: New directions in Research on Women and Entrepreneurship,' Gender, Work and Organisation, 6 (4), 224-235.

Mulholland, K. (1996) 'Gender and Property Relations within Entrepreneurial Wealthy Families', Gender, Work and Organisation, 3(2): 78-102.

Nicholson, L., and A.R. Anderson (2005). 'News and Nuances of the Entrepreneurial Myth and Metaphor: Linguistic games in entrepreneurial sense-making and sense-giving,' Entrepreneurship Theory and Practice, 29 (2), 153-172.

Neergard, H., and J.P. Ulhoi (2007). 'Introduction: Methodological variety in entrepreneurship research' in Handbook of Qualitative Methods in Entrepreneurship Research. Ed. H. Neergard and J.P. Ulhoi. Cheltenham: Edward Elgar Publishing Limited, $1-16$.

Ogbor, J.O. (2000). 'Mythicizing and reification in entrepreneurial discourse: ideologycritique of entrepreneurial studies,' Journal of Management Studies, 37 (5), 605-635.

Pitt, M. (1998). 'A tale of two gladiators: “'Reading', entrepreneurs as texts,' Organization Studies, 19 (3), 387-414.

Radu, M., and R. Redian-Collot (2008). 'The social representation of entrepreneurs in the French Press: Desirable and feasible models?' International Small Business Journal, 26 (3), 259-298. 
Reed, R. (1996). 'Entrepreneurialism and Paternalism in Australian Management: A Gender Critique of the "Self-made" Man,' in Men as Managers, Managers as Men, Critical Perspectives on Men, Masculinities and Managements. Ed. D. L. Collinson and J. Hearn. London: Sage, 99-122.

Riessman, C.K. (1993). Narrative Analysis. California: Sage.

Ricoeur, P. (1991a). 'Life in Quest of Narrative,' in On Paul Ricoeur: Narrative and Interpretation. Ed. D. Wood. London: Routledge.

Ricoeur, P. (1991b). 'Narrative Identity', in On Paul Ricoeur: Narrative and interpretation. Ed. D. Wood. London: Routledge.

Somers, M.R. (1994). 'The Narrative Constitution of Identity: A Relational and Network Approach,' Theory and Society, 23(5): 605-50.

Somers, M.R., and G.D. Gibson (1993). 'Reclaiming the Epistemological "Other": Narrative and the Social Constitution of Identity', Working paper series, Department of Sociology, University of Michigan Ann Arbor.

Somers, M.R. (1994). 'The narrative constitution of identity: a relational and network approach,' Theory and Society, 23 (5), 605-649.

Smith, R. (2005). 'The Fabrication of Entrepreneurial Fable: A bibliographical analysis,' Journal of Private Equity, 8 (4), 8-19.

Smith, R., and A.R Anderson (2004). 'The devil is in the e-tale: form and structure in the entrepreneurial narrative,' in Narrative and Discursive Approaches in Entrepreneurship. Ed. D. Hjorth and C. Steyaert. Cheltenham: Edward Elgar, 125-143 
Steyaert, C. (1997). 'A Qualitative Methodology for Process Studies of Entrepreneurship,' International Studies of Management \& Organisation, 27(3), 13-33.

Sunderland, J. (2004). Gendered Discourses. Basingstoke: Palgrave Macmillan.

Swan, E. (2006). 'Gendered leadership and management development: Therapeutic cultures at work,' in Women in Leadership and Management. Ed. D. McTavish and K. Miller. Cheltenham: Edward Elgar.

Talbot, M. M. (1998) Language and Gender: An Introduction. Cambridge: Polity Press.

Wagner, I., and R. Wodak (2006). 'Performing success: identifying strategies of selfpresentation in women's biographical narratives,' Discourse and Society, 17 (7): 385-411.

Warren, L. (2004). 'Negotiating entrepreneurial identity: communities of practice and changing discourses,' International Journal of Entrepreneurship and Innovation, 5 (1), $25-37$.

Watson, T.J. (2009). 'Entrepreneurial action, identity work and the use of multiple discursive resources: the case of a rapidly changing family business,' International Small Business Journal, 27 (3) 251-274.

White, H. (1991). 'The Metaphysics of Narrativity: Time and symbol in Ricoeur's philosophy of history' in On Paul Ricoeur: Narrative and Interpretation. Ed. D. Wood. London: Routledge.

Wood, D. (1991). Ed. On Paul Ricoeur: Narrative and Interpretation. London and New York: Routledge. 